\title{
THE QUALITY IN ELECTRONIC SERVICES JOGJA CITY GOVERNMENT: IN CASE E-KTP
}

\author{
Dody Harry Mulyanto \\ International Program of Government Affairs and Administration, \\ Universitas Muhammadiyah Yogyakarta \\ Email:dody.harry@yahoo.com
}

\begin{abstract}
This research aims to measure public service satisfaction through the electronic service in jogja city government.Tthis study is a qualitative research with descriptive analytic method. It also analyzest with normative theory as comparison. In this case, the research explore take of e-ktp, E-ktp has a profit for indonesian people who are as identity card, handle the country administration access and facilities easily, minimize dual population data, and there is no need to extend the card (for life). The jogja city government still has a lot of problem. Although 1900 society haven't receive an E-ktp, then Jogja city government should prepare with 4.0 era in which all of system use elecetronic. The author analyze and think how to increase satisfication quality service through electronic system.
\end{abstract}

Keywords: E-Service, Yogyakarta, Indonesia, Political Sciences, Public Policy, Governance, Quality Service.

\section{BACKGROUND}

From Geography aspects, Indonesia consist of big island and small island who are more than 13.000 who have kind of traditional and culture suddenly stand up various ethnic, because it needs one type of government who cares condition of other province. Due to every area as well as province has local government or province government. Based on Article 3 of the Third Law of 2014, local governments were the legislative ministers of local governments, who were led by municipalities in their acts of self-regulation of government authority. It also meant implementing the functions of local governments, local governments. The society will be satisfy from a quality service its government.
According to Tjiptono, Quality of service is a dynamic state closely linked to products and services, human resources and the environment that can exceed or improve the quality of minimum expected services. The definition of quality of this service relates to meeting the needs that arise with the customer's desire to meet the expectations and satisfaction of these customers. In good quality of service, there are many kinds of services, including service criteria Such as, Accurate the service time that includes waiting times during the transaction or payment process, Minimize mistakes of service in services or transaction, Be courteous and kind when providing services, Convenient to service is the availability of human resources for the availability of any product, i.e. helping to support any kind of

Dody Harry Mulyanto

Keywords: E-Service, Yogyakarta, Indonesia, Political Sciences, Public Policy, Governance, Quality Service. | 
product, and comfort of consumer such as a parking lot, a convenient waiting room, a hygienic aspect, and information availability.

Also Electronic Media can be defined as a medium that uses electronic or electrical energy for end users to connect to its content. The term is a contrast to static media that is generated electronically but that is required electronically and electronically for end-users to access. Sources of electronic media for other common users include video tapes, audio recordings, multimedia presentations and online content (Dhaou, 2018, \& 2018, n.d.).

New media is generally becoming digitized, but electronic media can have analog and digital forms. Increasingly, almost all activities can be done by electronic media. In this era, media electronic is multifunctional, especially for measuring satisfy about Quality service in the government. The government in this era, almost of all province already used electronic Service that help government makes easier working. Information and communications technology, as drivers, mean a significant view of the open government back office, but they are a "hidden side," and we agree that the ICT as drivers will focus and examine the key aspect (Jiménez et al., 2016)

For example, E-KTP While some of the empiric problems that arise from the District itself are related to the lack of availability of human resources / equipment, as evidenced by the lack of division of tasks between employees and only the presence of an operator officer in the E-KTP service and the lack of service available to support infrastructure facilities, E-K equipment is being manufactured.

In order to fulfill its duties in order to meet the needs and satisfaction of the public, it is important to be driven by service standards, namely: (1) service procedures should not be complicated; (2) a set turnaround period, (3) easily affordable costs; (4) reliability and value service products; (5) sufficient and comfortable facilities and services in the service process; (6) the competence of service provider officers must be nimble and responsive and can provide satisfaction to the community in the service process (Kemenpan Number 63 of 2003). The objective of implementing a decentralized system in the regions is to implement bureaucratic reform on all fronts.

The reform is expected to provide services that are more easily accessible to the general public. One of the benchmarks for the success of the bureaucratic reform is the quality of the services provided. Like the quality of the E-KTP services that are the subject of the analysis in this study, there are still a number of problems, both from internal and external organizations, so this research aims to find out how the quality of the E-KTP services in Jogja City is concerned.

Research question is how to increase quality electronic service in local government especially Jogja City?. Research purpose are This study aims to measure the satisfy of public service through the electronic service in society and government should make sure the society enjoyment the electronic service. Similar society should cover the era that using electronic in all of the sector. In addition, the characteristic of the urban planning and services. In this case, Yogyakarta government as this research. In other hand, the government also can increase the public services through electronic services. 


\section{LITERATURE REVIEW}

In some of the literature review above, there are some differences in the concept of Electronic service by researchers, comparison of governments, and Public Policies. Smart Government is the third indicator for Smart City. As one of the most powerful agents of Smart City, the government must be able to facilitate transformation and social development. For example, strategic economic regulations are designed to encourage the growth of small and mediumsized businesses and creative industries. Or by monitoring digital fines through the use of technology to reduce the intervention of reckless individuals. As a result, public trust in the government and transparency will be established. In addition, following the popularity of the Block chain system, the transparency of transactions will be easily monitored by the public.

In this case study, a distinction will be made between two central governments which are geographically and culturally very different, each of which have their own characteristics in the province. There are three components which relates with this paper are Public policy, Smart governance and electronic services. They relate each other. Actually the first appears smart city then smart city have several element which one of the element is smart governance later smart governance have indicator all of the services use electronic media to make easily the citizens. Exactly without Public Policy from government there will be no smart governance such as which will be explained by this paper.

\section{Public Policy}

The reasonable starting point is to decide what the research is actually studying.
That sounds simple enough, but public policy is maddeningly hard to pin down. Instead of identifying a single concept as the core focus of different activities, it might be easier to identify an area (or a field) rather than a core concept. Some may argue that this reassesses rather than fixes the definitional issue. While policy evaluation is largely an empirical exercise, policy analysis is more normative. The policy analysis focuses on ex ante issues. The most important of these is: what are we going to do? The objective is to determine the best policy for public authorities to adopt in order to address a particular problem or issue of concern. In particular, the process of providing services to the public (community) today is carried out through direct contact between service providers (government bureaucracies) and residents. As it turns out, direct contact such as this has been commonly used by customer engagement participants, both from officials (service providers) and from the public (service minimizer). As far as public citizenship is concerned, many unscrupulous people may wish to obtain services conveniently by bribing or offering "Pelican" cash against unscrupulous servants. Lasswell's vision of the political sciences and the political scientist was extended and refined in a series of publications between the 1940s and his death in 1978. The basic article, The Policy Orientation, was published in an edited volume in 1951. Here Lasswell tried to lay down the goals, strategies and objectives of the political sciences.

Such practices will certainly have an impact on other service users, which in turn will also have an impact on the quality of services in general. Public service is an activity or a series of activities to meet the needs of service providers in accordance with the laws and regulations of every citizen and 
resident of goods, services and/or administrative services performed by public service providers based on Law number 25 year 2009 Article number 1 (Holle, 2011)

As described above, public services or public services may be defined as all forms of public service activities carried out by the central, regional and environmental government agencies of the State-owned Enterprises (SOEs) and the Regional-Owned Business Entities (BUMD) in the form of goods and services, both in the sense of efforts to meet the needs of the community and in the context of their operations. The nature of Public Services include:

1. Improving the quality and productivity of the implementation of government duties and functions in the field of public services.

2. Encouraging efforts to make effective systems and governance of services, so that public services can be carried out more efficiently and effectively.

3. Encourage the growth of creativity, initiative, and community participation in the pace of development as well as efforts to improve the welfare of the wider community.

Systems, changes in local administration and other institution-building processes. The central issue in modem bureaucratic reorganization is which organizational structures are used and should be used for the implementation of public policies and programs: regulatory agencies with impartial and qualified executive officers, staff appointed on the basis of political merit, local administration, corporatist arrangements, professionals, client participation, etc. It goes without saying that the evaluation includes the assessment of both substantive and process-oriented government interventions.

The evaluation focuses on all kinds of public sector activities. The delivery of public services by the government apparatus to the public is an expression of the role of the state apparatus, so that the development of a system of public service practices and acts by the government apparatus requires a general framework in the form of guidelines for public service governance. This guidance addresses issues that need to be resolved in the procedures for the operationalization of public services provided by government agencies at the central and local levels in an open and transparent manner.

Policy analysis approach cannot be reduced to the principles and theoretical practices of microeconomics, since solutions to practical problems require much more than rational choice analysis, anticipated utility, and opportunity costs. Likewise, the methodology of policy analysis cannot be reduced to the study of politics, since solutions to practical problems require more than an analysis of power, law, and authority, or who gets what, where, and how. There's a lot more involved. Ultimately, because the main objective of the policy analysis is to strengthen policies, the methodology of the policy analysis cannot be reduced to an abstract spectator sport in which information is respected.(Dunn, 2015)

We recognize that each country has a definition of the public interest interests of the people for the state and their respective countries, which are usually referred to as national interests. National interest in Indonesia, as we can see from the opening of the Constitution of 1945, are three components of that national interest that are 1) promote general welfare 2) educate the life 
of the nation and 3) Participate in carrying out world order. Although it must pay attention to the conditions and situations and the main criteria in determining public policy, while the decision-making process for public policy has a futuristic nature that is linked to the future, it is necessary to try to find and consider alternatives. Decision as much as possible And only then do you choose an alternative. The best that has effects, effects and benefits that are good for society and the country. Government policies must be good, or because the desires, opinions and desires in the community are different, then the decision-making must be as good as possible the size of which is the public interest.

Then it is the duty of the government to regulate the lives of the people as well as they can. Therefore in Indonesia, the National interests listed in the opening of the 1945 Constitution are a measure that must always be considered by the government in making decisions in policy. ideal public policy is a public policy that builds the competitive advantage of every individual Indonesian people both men and women without differentiating each Indonesian family, every organization both society and government.

The distribution of rewards in society is simply and massively unequal. The pluralists were not in agreement with this statement. We did not question John F. Kennedy's aphorism that "life is unfair," nor did we relinquish their willingness to do something about it by protest, change, and grievance redress. What they denied was that the cost-benefit ratio for injustices often accrues to the advantage of the same small class. They argued that conflicts of interest give rise to a many-sided, if not always just, mix of deprivation and reward for various elements of the population, that these conflicts do not result in a simple, one-sided outcome (Draper, 2017).

A statement, which is definitely well known in many empiric analyses of recent American politics, has been that any two-tier analysis of the result of the group conflict is a distortion; in reality, the group conflict spreads its rewards broadly. Thus, at one end of the spectrum, the problems of tame are currently considered to be capable of standard or routine solutions. The low levels of ambiguity and conflict and thus low levels of perceived uncertainty (Head \& Alford, n.d.). Of course, Sometimes, some of these problems can come to be seen as more contentious or more complex and may involve other methods and solutions. Tackling key challenges through non-standard adaptive management and networked governance processes is becoming more relevant as issues show higher levels of complexity and stakeholder competitions, for example, where key players follow divergent approaches to problem concepts and possible solutions. The goal of policy analysis is to set a benchmark for evaluating what is "best." Quality and efficacy, for instance, are both defensive metrics for determining what is, or is not, the best policy to tackle a particular issue or topic of concern. However, the most efficient policy is not necessarily the most effective, and vice versa(Smith, 2018).

The Policy sciences have been described by their emphasis on the major problems and issues facing the nation. This focus was not limited to the actual or anticipated outcomes of government programs or policies. The formation and adoption, as well as the execution and assessment of specific choices were among the main problems. The key focus of the policy scientist was not on a specific stage of 
policy making (analysis, evaluation, process), but rather on an important issue facing the government (Smith, 2018) although it is not immediately clear what ties the work of a political scientist researching the creation of political subsystem coalitions to, say, a program evaluator conducting randomized field trials on job training programs, those connections certainly exist. On the one hand, many (if not all) of the sub-fields under the umbrella of policy studies trace back to a common historical source. Those who see their work as shaping policy in the name of the public good, on the other hand, may find themselves less than satisfied with a mathematically and theoretically complex approach to public policy.

The technocratic orientation of the sciences of policy can be particularly frustrating for those who are bent on advocacy; the very notion of reducing, say, proposed health programs to cost-benefit ratios seems to some to be misleading or even preposterous. Simplified writing style, cases based on real-world analytical practices, and visual displays that make complex ideas understandable. Definitions and case studies now include topics of foreign policy and international security as well as domestic issues, including environmental justice, urban development, transport and public safety (Dunn et al., 2012).

The application of public policy is the implementation or application of public policy by services, events, acts or actions in a process that is bound by a particular system.(Ramdhani, Muhammad, \& Ramdhani, n.d.) policies are collective practices; policies are not individual or separate policies. Thus, the policy is something produced by the government that is formulated on the basis of all the events that take place in the community. This activity arose in the context of social life, and it was not an occurrence that was unique, separate and alien to the group. Policy is a response to the events that are taking place, both in order to create harmony between conflicting parties and to create incentives for joint action for parties who are irrationally treating the joint effort. Therefore, strategy can be defined as an effort to achieve certain goals, as well as an effort to solve problems by certain means and at certain times. General policies are fundamental, as policies simply prescribe general guidelines as a framework for action in order to achieve the stated objectives.

\section{Electronic Service}

Law No. 25 of 2009 on the Public Service requires the public service as a set of activities designed to meet the need for a service that is consistent with the law of every person and community over the item, service or administrative service provided by the public service provider (Setyowati, 2016) stated that e-Government is to simplify service electronically. E-Services, definitely the process of delivery of services using information and communication technologies, with which public service officers no longer meet in person (similarly) with community service users.

As a result, the administration practices mentioned above are no longer easy. Services no longer see who is being served directly because they are only connected to technology(Febry, n.d.) the aim of e-service is also to promote good governance. The use of technology that makes access to information easier for people can reduce corruption by increasing the transparency and accountability of public institutions. Electronic services can increase public participation where the public 
is allowed to participate actively in government decision-making or policy activities. It is also expected to improve administrative productivity and efficiency and to increase economic growth. (Dye, 2012) describes the public policy as "whatever governments choose to do or not to do," this definition means that if the government chooses to do something, it must have goals, objectives or priorities set by the government that will have as much impact on society as government action. The implementation process of the policies issued by the Government must be directed towards the targets that have been set in order to see the public interest that must be followed.

In the sense of public administration, the principles of achieving the goals of public policy, namely the provision of health-related services, education, national defense, etc., for the fulfillment of public demands and the acquisition of personal care, etc. However, in fact, particularly in Indonesia, only a few local governments have been able to develop their digital services for the purpose of providing services to the public from a number of studies on the creation of electronic services for public service purposes.

In summary, the goals to be accomplished through the introduction of digital services are to create online and not online consumers. Digital services are designed to provide networks without the intervention of staff of public institutions and a long queuing period simply to provide a simple service. With the implementation of the development process in accordance with the principles of good governance, local governments are expected to incorporate and use information technology technologies to improve the ability to control municipal budgets and to deliver financial information to the public so that there is good public accountability (Fajarsyah Putra, Saputra, 2017). Identify indicators as tools for measuring the quality of electronic services, namely:

- Reliability, namely the ability of the company to provide appropriate and satisfying services.

- Website Design, which includes all elements of consumer experience on the company's website, including navigation, searching for information, processing of requests and appropriate personalization.

- Safety, definitely safety of payment and confidentiality of consumer information

- Customer Service, which is a service used to solve the problems of responsiveness and The willingness of the company to help the problems of the customer.

Consumer behavior can be predicted by intention or intensity, the most effective way to find out whether or not an individual will display a behavior is to ask or know the individual's intention to perform a behavior. The intent of the complaint is motivated by the failure of the company to offer a product or service that satisfies the customer's needs, and the customer will tend to make plans or take action to communicate his disappointment (Andriyas \& Herlangga Himawan, 2019).

Ideal public policy is a public policy that creates the competitive advantage of every person of the Indonesian people, whether men and women, without discriminating between every Indonesian family, every organization, both the society and the state, both for-profit and non-profit. 
Therefore, the end result of a public policy is the consequences or impacts that are truly felt by the community, both expected and unexpected as a consequence of government action or the absence of government action in the field of certain fields or problems in society. The most important thing, however, is to make public policy a measure of the interests of the community in order to produce a good and ideal policy outcome.

\section{Smart Governance}

Management of democracy-related business processes using Intelligently Networked Information and Communication Technologies (ICT) intelligently networked governance uses the opportunities of interconnected smart objects and cyberphysical systems to perform public tasks efficiently and effectively (waltungs \& 2016, n.d.).

Smart governance is defined as a subset of the smart city domain where open dialog between citizens and city officials is made possible through an ICT platform and another definition is Indeed, the system, one of the smart city dimensions. Nevertheless, the use of this word is still rather vague and, in this regard, it must be distinguished by a given approach. Which smart governments are implementing smart governance initiatives. In addition, information gathering, dialog enablement, decision-making and assessment are four main participatory phases of the smart governance platforms. In addition, due to lack of standardization, a common smart city architecture that serves governmental purposes for innovation and sustainability has been identified.(Reforgiato Recupero et al., n.d.)

Smart urban projects and initiatives have a major impact on the quality of life of citizens. Citizens are at the heart of a city and the key to a number of challenges facing cities through ongoing urbanization and demographic growth, consumption patterns and increasing expectations. Therefore, they must be at the heart of the solution. Citizens have always been insufficiently engaged, motivated and empowered to make a contribution. In addition, cities have no deep knowledge of their citizens to actively engage them. With a better understanding of their motivations, cities can define effective strategies and tools to encourage citizens to become players in smart city systems.

In this context, the application of Semantic Web technologies to smart cities has an extremely high potential and impact (Bischof S. et al., 2014) and could provide a tool for unifying and facilitating data integration from multiple heterogeneous sources. The use of cloud computing technologies can increase and improve the final outcome of smart cities ' solutions. The International Telecommunications Union (ITU) (ITU, 2015) has compiled a broad conceptual context to provide a smart sustainable ICT city with a meta-architecture that can offer several benefits: I lower software development, support and maintenance costs; (ii) more device portability and (iii) interoperability; (iv) enhanced smart services; and (v) shortened time-to-market for them.

The cloud provides significant computational power for decision-making and policy development frameworks and data management from heterogeneous sources and domains. Nevertheless, the cloud computing approach poses several technical challenges due to the interoperability of database systems and the implementation of reference standards. In fact, a smart city consists of 
several different domains (transport, power, land use, government); thus, the amount of data to be managed is massive and heterogeneous4. One ICT solution to this problem is Big Data technologies that can collect, process and integrate vast amounts of data in almost real-time and share them through interoperable cloud-based services.

The link between Government \& Governance and Citizenship \& Cities within the Information \& Knowledge Society is key to a new view of our world as a "system" in which its optimal status should be to achieve the highest degree of governance within a city in which its benefits are maximized and its disadvantages minimized (Jiménez et al., 2016).

Governments play a crucial role in the growth of smart cities through financing these investments. In addition, smart governance is among the six smart city dimensions and involves the transformation of local government into transparent, effective and accessible to its people through the use of ICT, as well as the creation of acceptable smart city policies (Anthopoulos \& Reddick, n.d.). However, with the contributions of political and informational sciences, the terms intelligent governance and intelligent government emerging, and in this respect, their clever administration refers exclusively to the smart city government, or to a different domain or either. Smart city was a somewhat "smart" subject until recently, when several scientists were able to better define it. (Anthopoulos \& Reddick, n.d.) present a claim that intelligent governments use the power of "data" to enhance public services; enable integrated and seamless service experiences; engage with citizens; develop policies jointly; and deploy communitywelfare solutions.
Smart government transition includes the engagement of people, openness of knowledge and enhancement of services. Since the terms smart government and smart governance in literature are used, a distinction must be noted: Government occurs in cases when those with legal and formal powers and the police carry out or implement their activities, and Governance refers to the creation, performance, and implementation of actions supported by common goals of citizens and organizations, who may or may not carry out such activities.

\section{RESEARCH METHOD}

This paper is a qualitative research with descriptive analytic method. This study analyzes data and analyzes it with normative theory as a comparison. Field observations were made in the city of Jogjaa, Qualitative methods are more focused on the discussion and explanation of a particular, not just looking for cause and effect on the phenomenon being discussed. Interpretation of reality and discourse can be done using qualitative research itself which is used because it prioritizes the quality of analysis and not statistical data.

\section{Data Sources}

This is a written source of data that is used as supporting information in primary analysis. Secondary data is data collected from second hand or other sources available before the research is conducted. Data collected through other available sources is called secondary data. Secondary sources include comments, interpretations, or discussions about the original material. Secondary sources can be referred to as "second hand information" (Silalahi, 2010: 289). 
For this analysis, data collection uses several of methods to obtain complete information. Document study is a form of collection of data and study documents where documentation that is deemed supportive and relevant to the problem to be examined is examined, reviewed and categorized in such a way that data are available in literary form, annual reports, newspapers, tables, scientific papers on government regulatory documents and available laws related institutions. techniques of data collection of the necessary object data, the techniques used are:

1. Library research, which is a means of gathering information using existing research books or existing research literature.

2. Search for online data or using the web.

The author uses a technique of triangulation to check data validity. Triangulation is a data verification technique that uses something else according to (Lutsky, 2009). Data shall be checked or compared for the purposes outside. This technique is used by the researcher to eliminate the differences in the construction of reality in a study while collecting data from different perspectives on events and relationships. Data reduction is a selection, simplification, abstraction and transformation process for the initial data arising from written field records. This data reduction takes place continuously during qualitative research (Maxwell, 1992). In this study, researchers chose the data obtained at the time of the study regarding the perceptions of librarians about librarians, then the data was classified and selected simply.

\section{FINDING AND DISCUSSION}

In this era, public service is one of the areas that is the government's primary concern, because the public service sector is a significant factor in a country's success or failure. There are so many ways to create an atmosphere of healthy and good public service including the public service process laws and regulations. Until now there are 422,732 people in Jogja that have been validated by the Jogja city government The newest data show that approximately 1.900 people are living in the city of Yogyakarta, who have not recorded population data.

But irresponsibility still exists and the community is always the victim of course. Mismanagement occurs not only once or twice but often leads to losses for many people. Jogja City, in comparison to other districts of the DIY province, is a modern city. Included in good governance metrics, namely smart governance or smart government, would that be electronic service. Particularly, there are intelligently designed solutions which use almost every device as a medium for electronics. Services such as this should in this modern era be really clean and leave no trace. On the other side, this aspect is not only from its residents, but the performance of digital services like this can be influenced by a bureaucrat. For example, since most officers still do not yet know how to use the internet or applications used for the registration of electronic KTP, there are irregularities that our own government cannot overcome, so they still rely on certain people who are reliable in this field. Such things hamper or not even do the process of public service.

Of course, training using high-tech or sophisticated software should be given to how to improve the quality of digital services, by increasing the quality of supporters, such as those using advanced-tech computers, on the other hand, so that it is easy to implement the electronic public service system. On the other hand, online services must also be 
communicated to the public so that both consumers and operators are supplementary. A high level of government public confidence will be granted and the quality of electronic services will be improved, in particular EKTP which still has no E-KTP records for 1,900 individuals. In addition, E-KTP has important definitions, which can truly help us in our country and even abroad to enforce administrative processes. The society therefore requires an E-KTP

Of course, the municipal government of Jogja must not forget that with 4.0 the population of Jogja should have access to all government processes. The city of Jogja then has developments that use high technology in 4.0 already. As the city of Jogja itself has used electronic media as a form of public services from 2016 as Indonesia also aims at using online services in all cities in 2020 which means Smart government implements All of province in Indonesia. The City of Jogja also has a social agency to help DISDUKCAPIL, namely UPIK itself, to coordinate information and complaints on services within the Government of the City of Yogyakarta. Therefore, in carrying out this task the information submissioned by the public is given by media provided by the government of Yogyakarta, which includes, directly or indirectly, statements / news, grievances / claims, concerns, criticisms, queries, proposals and good suggestions. Incoming data is also transmitted by means of accessible media / facilities to UPIK Admin and UPIK operators. After this, something else that needs to be done correctly is to provide the group with answers based on information provided from the organization / official.

It also performs stock issues and works on solutions, as well as report regular grievances to the Deputy Mayor of Yogyakarta through the Head Part of the results of information and service operations. Capable of using and providing useful data for government work encouraging the execution and promoting the completion of projects, both key tasks and the support of tasks can be easily performed in a timely and efficient manner, saving money in use.

\section{CONCLUSION}

In my opinion, the Jogja City Government still has a lot to Challenge. Although only 1900 citizens do not receive an E-ID card, in other fields the Jogja municipal government needs to improve. The solution for me, the City Government of Jogja should educate people, and of course the bureaucrats who are active in the area of computers, if at all possible, can use software, intelligent administration and smart service not only the officers working in that field but all bureaucrats. Since the local community must be facilitated with internet access in this modern era without coming to the government, the community must of course also be restricted to what can be accessed from the website of the municipal government of Jogja and public service quality by electronic media must also be accessible for government, So as to improve the quality of electronic services in the city of Yogyakarta and mutual benefit from each other.

The e-KTP is the identity of an Indonesian citizen who, in the sense of both physical and computerized functions, is essentially personal data made electronically. The E-KTP program introduced by the Republic of Indonesia's Ministry of Home Affairs The E-KTP program has been launched in Indonesia since 2009 with the designation of four cities as national research 
projects. Padang, Makassar, Yogyakarta, Denpasar are the four towns. While in February 2011, the Ministry of Home Affairs officially launched other regencies / cities, the implementation of which was split into two phases. The first implementation phase began in 2011 and ended on April 30, 2012, comprising 67 million residents in 2348 subdistricts and 197 districts / cities. Overall, it is expected that at least 172 million people will already have ID cards at the end of 2012 and that population data will continue to be recorded from the beginning to the end of 2013 until all Indonesians are required to record their personal data. There are advantages and disadvantages of using the eID card in the e-ID card.

\section{REFERENCES}

Andriyas, H., \& Herlangga Himawan, G. (2019). Analisa Persepsi Konsumen Atas Kualitas Pelayanan Elektronik Terhadap Niat Komplain Konsumen Massively Multiplayer Online Role-Playing Games, 11(2), 248-261. Retrieved from http://journal.maranatha.edu

Anthopoulos, L., \& Reddick, C. G. (n.d.). Smart City and Smart Government: Synonymous or Complementary? https://doi.org/10.1145/2872518.288861 5

Dhaou, S., 2018, I. R.-E.-C., \& 2018, undefined. (n.d.). Global Challenge of Identity: Blockchain E-ID System for a Sustainable Development and Good Governance. Books.Google.Com. Retrieved from https://books.google.com/books?hl=en\&l $\mathrm{r}=\& \mathrm{id}=\mathrm{NzVxDwAAQBAJ} \&$ oi $=$ fnd $\& p g=$ PA199\&dq=electronic + service+quality+ of + electronic+identity \&ots $=$ sBojl31EFO \&sig=_zm9BHIPKdMpl2DS5d3sSilAVf
$\mathrm{E}$

Draper, T. (2017). American business and public policy: The politics of foreign trade. Retrieved from https://content.taylorfrancis.com/books/d ownload?dac $=$ C2017-0-50187$9 \&$ isbn $=9781351315630 \&$ format $=$ googl ePreviewPdf

Dunn, W. N., Columbus, B., New, I., San, Y., Upper, F., River, S., ... Tokyo, T. (2012). Public Policy Analysis Fifth Edition. Retrieved from www.pearsonhighered.com

Febry, M. (n.d.). Pelayanan Publik Melalui Electronic Government: Upaya Meminimalisir Praktek Maladministrasi Dalam Meningkatan Public Service.

Head, B., \& Alford, J. (n.d.). Public policy reconsidered View project complex and wicked problems View project. https://doi.org/10.1177/00953997134816 01

Jiménez, C. E., Falcone, F., Solanas, A., Puyosa, H., Zoughbi, S., \& González, F. (2016). Smart government: Opportunities and challenges in smart cities development. Civil and Environmental Engineering: Concepts, Methodologies, Tools, and Applications, 3 , 1454-1472. https://doi.org/10.4018/978-1-46669619-8.ch066

Partisipasi Masyarakat, P., Kebijakan Publik dan Pengetahuan Anggota Dewan terhadap Pengawasan Anggaran Pendapatan Belanja Daerah Fajarsyah Putra, T., Saputra, M., Studi Magister Akuntansi Fakultas Ekonomi dan Bisnis Universitas Syiah Kuala, P., \& Akuntansi Fakultas Ekonomi dan Bisnis Universitas Syiah Kuala, J. (2017). (No Title) (Vol. 10). Retrieved from 
http://jurnal.unsyiah.ac.id/tra

Ramdhani, A., Muhammad, ; \& Ramdhani, A. (n.d.). Konsep Umum Pelaksanaan Kebijakan Publik. Retrieved from www.jurnal.uniga.ac.id

Reforgiato Recupero, D., Castronovo, M., Consoli, S., Costanzo, T., Gangemi, A., Grasso, L., ... Spampinato, E. (n.d.). An innovative, open, cloud, interoperable citizen engagement platform for smart government and users' interaction. Retrieved from http://www.ubmfuturecities.com/author.a sp?section_id=234\&doc_id=526607

Setyowati, K. (2016). Quality of Electronic Identity Card Service by Demographic and Civil Registration Service in
Indonesia. The Impact of Information Technology on Social and Political Dynamics, 2017. https://doi.org/10.18502/kss.v2i4.898

Smith, K. (2018). The public policy theory primer. Retrieved from https://content.taylorfrancis.com/books/d ownload?dac $=$ C2017-0-75879-

$5 \&$ isbn $=9780429962905 \&$ format $=$ googl ePreviewPdf

waltungs, J. V. L.-I. vernetztes R. Ver, \& 2016, undefined. (n.d.). Smart Government. Zorde.Com. Retrieved from https://www.zorde.com/IoE/PerthSmart-Government-Insight-IoT-ENV2.pdf 